\title{
Population Densities AND COMMUNity STRUCTURE OF BIRDS IN JACKSON HOLE: A REASSESSMENT AfTER 25 YeARS
}

\author{
MARTIN L. CODY $\bullet$ DEPARTMENT OF BIOLOGY \\ UNIVERSITY OF CALIFORNIA $\bullet$ LOS ANGELES
}

\section{- INTRODUCTION}

There is a wide literature in bird community ecology that bears on questions of species composition and species densities, and the variations in these attributes within habitats between years and between different geographic regions, and between habitat types both locally and regionally (Cody 1975, 1985; Diamond \& Case 1986). While there has always been considerable debate on the constancy of bird communities within habitats and among years, and the extent to which community attributes are predictable and deterministic, rather than variable, stochastic or even chaotic (e.g. Wiens 1985, 1988), recently other developments have accentuated the need for measuring and evaluating bird distributions and densities. There is a fast-developing literature that documents recent (ca. the last decade or two) declines in bird species' distributions and densities at both local and regional scales, and emphasizes in particular evidence for recent reductions in the ranges and densities of bird species that are neotropical migrants (e.g. Hutto 1980, 1986; Keast \& Morton 1980; Terborgh 1989; Smithsonian 1991).

Given especially the concern that bird species breeding in North American sites and overwintering at lower latitudes (where habitat destruction and fragmentation are particularly rapid), data on status changes in breeding bird communities need to be carefully monitored. The best, perhaps the only, way of doing this is to collect current data, to contrast with comparable data collected in a similar fashion in earlier periods.

Thus the rationale for this study is apparent: during 1966-68 I obtained extensive data on the bird communities at two sites in Jackson Hole within Grand Teton National Park, located near the site of the old Research Station on the north side of the Snake River below the dam at Jackson Lake. During two field seasons 1991-92 I reassessed the bird communities at these two sites, with the major objective being a documentation of whether, in which ways, and to what extent, the bird communities of the two sites had changed over the 25 -year period.

The birds in Jackson Hole are particularly appropriate for this 25-year, then-and-now comparison, since none of the dominant species at the two study sites is resident. But while some species winter almost wholly within the United States (e.g. Fox sparrow (Passerella ilaca), other species winter in northern Mexico in desert habitats (e.g. Brewer's sparrow Spizella breweri, Chipping sparrow Spizella passerina) or west-coastal second growth habitats (e.g. Yellow warbler Dendroica petechia, Common Yellowthroat Geothlypis trichas), and yet others winter much further south into Central America (e.g. MacGillivray's warbler Oporornis tolmei, Wilson's warbler Wilsonia pusilla).

The results of the comparison are presented in this report, where differences in species 
composition and density are revealed in both the short-term (adjacent years) and the longer term (between censuses over 25 years apart). But despite such variations, it will be noted that the overall community structure and composition of the sites has changed little over the quarter century.

\section{$-\quad$ STUDY AREAS}

During breeding seasons in 1966-68, two study sites were established within Grand Teton National Park; both are close to each other, within a few hundred meters of Jackson Lake Junction and of the site of the old Research Station. These sites are

a) Willow scrub habitat, WS, ca. $250 \mathrm{~m} \mathrm{~W}$ of Jackson Lake Junction and $50 \mathrm{~m}$ north of the road between the junction and Jackson Lake Dam. This site is dominated by several species of willow (Salix spp.), species with different characteristic heights between $<1 \mathrm{~m}$ and ca. $3 \mathrm{~m}$. An assortment of other small shrubs occur as occasional plants around willow clumps (e.g. Lonicera, Symphoricarpos). Small glades interdigitate among the willows, where typical meadowland grasses and forbs thrive (e.g. Geranium, Castilleja, Potentilla), and the site is dissected by several streams, along which riparian plants occur, particularly around the intermittent ponds above beaver dams, of which several both new and old are sited within the study area.

b) Sagebrush-grass/forb meadow, GS, ca. $250 \mathrm{~m} \mathrm{SE}$ of Jackson Lake Junction, in the flats adjacent to the Snake River east of the old Research Station. This site is dominated by two sagebrush species, but of these Artemisia tridentata is far commoner than A. cana. Interspersed among the sagebrush are patches of typical meadowland grasses and forbs, including some rather large patches of Wyethia in drier sites with shallower soils. Within the denser sagebrush, where grass and forb cover is generally very low, the commonest forbs are three caespitose Eriogonum species.

In the 1991 season the two study sites were re-activated in the park, in locations as nearly overlapping as possible the sites worked previously (1966-1968). Each site was re-established with a 15 $\mathrm{m} \times 15 \mathrm{~m}$ reference grid. In the grass-sagebrush GS site, overlap between the 1991 site and the 1966 study area (Cody 1974, 1985) is estimated to be 95\%; in the willow scrub WS site, overlap with the previous site is estimated to be $70 \%$. A partial relocation of the WS site was necessitated by extensive flooding of the old site, a product of high water levels within the willows area and a late 1991 season, and the influence on these factors by a great deal more beaver activity at the site than was seen in 1966-68. In the 1992 season the same two sites, with the same grid reference systems, were employed for completion of the project.

Both sites were heavily browsed by both moose and deer, but otherwise enjoyed little or no disturbance by humans, except for the observer.

\section{$\checkmark \quad$ METHODS}

The censused and mapped WS site comprised $9815 \mathrm{~m} \mathrm{X} 15 \mathrm{~m}$ quadrats originally, and was expanded to include 145 quadrats, some 3.26 ha., in 1992. At the GS site some $22015 \mathrm{~m} \mathrm{X} 15 \mathrm{~m}$ quadrats were originally employed, and 208 quadrats, totaling 4.68 ha., were used in 1992. Breeding bird censuses were made in 1991 during two time periods, June 15-27 and July 30-August 9, and in 1992 the period June 15-July 28. Territorial activity of the resident birds was mapped using the "spot-mapping" technique. The locations and movements of all bird species under consideration were plotted on scale maps of the two sites. Such records were collected on successive morning census periods, $0700 \mathrm{~h}-1100 \mathrm{~h}$, over 5 days in the GS and over 10 days in the WS. At the end of the census periods, the activity records were cumulated on master census maps, and the estimates of territory positions and sizes computed. These census data enabled estimates of species composition, breeding densities, and territory sizes to be made. Together with information on vegetation structure (see below), intraspecific interactions relative to vegetation structure and interspecific interactions over habitat could be computed in each of the two sites.

Vegetation measures were made within each $15 \mathrm{~m} \mathrm{X} 15 \mathrm{~m}$ quadrat, in GS in 1991 and WS in 1992. In GS foliage profiles were measured in each quadrat, plots of vegetation height versus vegetation density. These foliage profiles were measured from the center of each quadrat along four orthogonal directions based on the (varying) position of the sun 
with respect to the observer. Distances to a board that would be half-covered by vegetation were estimated along each of the four axes, at heights above the ground as follows: $7.5 \mathrm{~cm}, 15 \mathrm{~cm}, 23 \mathrm{~cm}$, $30.5 \mathrm{~cm}, 46 \mathrm{~cm}, 61 \mathrm{~cm}, 76 \mathrm{~cm}, 91 \mathrm{~cm}$ and $122 \mathrm{~cm}$. The reciprocals of these distances were averaged for each quadrat, and their plot, versus height above the ground, constitutes the foliage profile of the quadrat. The areas under the foliage profile between adjacent heights, and above height $122 \mathrm{~cm}$, correspond to the amount of vegetation for those specific height intervals. Various multivariate statistics (principal components, discriminant functions) were performed on the 208 sets of (quadrat-specific) areas.

In the WS site, vegetation height was mapped within each quadrat, and the proportion of each quadrat that was covered with open water (WATER), meadowland grasses and forbs (GRASS), and willows reaching heights less than $0.61 \mathrm{~m}$ (FT2), $1.22 \mathrm{~m}$ (FT4), $1.83 \mathrm{~m}$ (FT6), $2.44 \mathrm{~m}$ (FT8), $3.05 \mathrm{~m}$ (FT10), $3.66 \mathrm{~m}$ (FT12), and $4.27 \mathrm{~m}$ (FT14) was calculated. For some purposes these 9 variables were reduced to 8 (by omitting WATER), or to 5 (by combining FT6 and FT8 into the variable MED, for "medium-high willows", and FT10, FT12, and FT14 into the variable TALL, for "tall willows"). These variables served to measure vegetation structure, and the responses of the bird species to variations in vegetation structure, and were similarly treated with multivariate statistical techniques (see below).

Foraging behavior and foraging height activity was measured for each passerine bird species present. Foraging records for each of the commoner bird species were accumulated to show the locations and heights above ground where each species spent foraging time. These records were assembled into foraging height histograms that a) characterize each species and b) serve to contrast different species in the same habitat.

All species at the sites, at least in the breeding season, are insectivorous; insect availability was estimated, in the WS site only, using stickyboard traps. These are white styrofoam plaques, $10 \mathrm{~cm} \mathrm{X}$ $10 \mathrm{~cm}$ in size, suspended at different heights within the vegetation using wire clips. The plaques were covered with Tanglefoot, a sticky wood-resin derivative, to a uniform density. Plaques were positioned flat on the ground (one up-side only sticky), and at heights of $0.5 \mathrm{~m}, 1 \mathrm{~m} .1 .5 \mathrm{~m}, 2 \mathrm{~m}$ and $3 \mathrm{~m}$ above ground at each trapping station (both sides sticky). The plaques at each trapping station were located within $5 \mathrm{~m}$ of each other. A similar arrangement of plaques was followed at each trapping station, with a new station being initiated each day over a five-day period. At a specific time $(1100 \mathrm{~h})$ each day, previously set insect traps were visited, and all insects were removed, counted, and placed in one of 4 size categories, and the Tanglefoot refreshed as needed.

\section{$\checkmark \quad$ RESUlts}

\section{6-68 BIRD COMMUNITIES}

In the course of the earlier work, I obtained detailed information on two main aspects of the bird communities. a) The territories of all breeding species at the sites were mapped, and the disposition of the territories analyzed with respect to vegetation structure and in relation to the location of territories of the other species present. Thus species identities, densities, habitat preferences and interactions among species over the use of space were determined. b) The foraging behavior and foraging height distributions of all species were measured, and the density, size- and height-distributions of their insect prey quantified.

Table 1 lists all bird species seen at the two sites over all census periods. In the WS site, the commonest bird species were those in two guilds: four paruline warbler species and five emberizine finches. In each guild the species segregate chiefly by foraging height, but independently between guilds (Cody 1974). From high to low in the vegetation, the species are, in the parulines: MacGillivray's warbler, Wilson's warbler, Yellow warbler, and Northern yellowthroat; and in the emberizines: Claycolored sparrow, Lincoln's sparrow Melospiza lincolnii, white-crowned sparrow Zonotrichia leucophrys, fox sparrow, song sparrow Melospiza melodia. The lowest two emberizines also take insects from the ground and from low herbaceous vegetation, while the highest two parulines also take insects by hover-gleaning and aerial flycatching. No behavioral interactions were observed among these willows species, and the disposition of territories was explained by variations in preferred vegetation structure alone. 
Table 1. Bird species present in breeding season in two GTNP sites (all species recorded within sites; data for 1966-68 and 1991-92.

Willows WS

Grass-sage GS

Dominant breeding species; territories mapped and densities assessed:

Yellowthroat

Yellow warbler

Brewer's sparrow

Wilson's warbler

Vesper sparrow

Fox sparrow

Savannah sparrow

Lincoln's sparrow

White-crowned sparrow

Song sparrow

White-crowned sparrow

Willow flycatcher

Species found breeding within sites, but not every year (territories mapped*):

Clay-colored sparrow*

Swainson's thrush*

Calliope hummingbird*

Black-billed magpie

Northern waterthrush*

Marsh wren*

MacGillivray's warbler*

Species found feeding either regularly* (most years) or occassionally within sites:

Northern flicker

Raven

Northern flicker*

American crow

Raven

American crow

Robin

Black-capped chickadee

Brown-headed cowbird

Cliff swallow*

Violet-green swallow

Black-billed magpie

Robin*

Starling*

Brown-headed cowbird*

Barn swallow*

Cliff swallow*

Rough-winged swallow

Savannah sparrow

Tree swallow*

Cedar waxwing

Brewer's blackbird*

Marsh hawk

Species associated with wetter habitat within the sites.

Virginia rail

Coot

Snipe

Snipe

Kildeer

Kildeer

Bufflehead

Green-winged teal

Red-winged blackbird 
In the grass-sagebrush GS habitat, a major part of the total bird density is comprised of three emberizine finches typical of sagebrush flats: Brewer's sparrow, white-crowned sparrow, and vesper sparrow Pooecetes gramineus: grassy areas in the sagebrush support a fourth species, savannah sparrow Passerculus sandwichensis. These species differ in size and the proportion of time spent foraging off the ground in the brush, and among the first three I found no direct interactions. However, there were strong interactions between savannah sparrows and the first three species, as measured by the disparity between interspecific overlaps in vegetation structure (habitat preference) within the territories of each species, and the interspecific (spatial) overlap in territories (Cody 1974, 1985).

\section{THE GRASS-SAGEBRUSH SITE}

For the GS plot, similarities and differences in bird species composition and density, 1966-19911992, can be seen in Table 2. These can be summarized as follows:

a) A $10 \%$ overall reduction in habitat occupancy and density of emberizids was noted in 1991 (from 2.40 to $2.24 \mathrm{pr} / \mathrm{ha}$ ), but a subsequent increase occurred in 1992 (up to $2.78 \mathrm{pr} / \mathrm{ha}$ ); the overall bird densities at the site in 1991 and 1992 bracket the value obtained in 1966 .

b) White-crowned sparrow density was constant at the site over the 25-year period, over which time Vesper sparrows decreased $26 \%$ while Savannah sparrows increased by $70 \%$. However, the greater part of the Savannah sparrow change was observed between adjacent years (50\%, 1991-1992), and the greatest change in Brewer's sparrow densities was also observed in the $40 \%$ increase between 1991 and 1992.

c) A new species, Chipping sparrow $S$. passerina bred just off-site but foraged within the site in 1991, but did not recur in 1992. Starlings, which were not present at the site in 1966, foraged commonly at the site in 1991-92, and also constitute an addition.

Principal components of profile areas for the quadrats in GS show that $2 / 3$ of the total variance is accounted for in the first two factors; FACTOR 1 is strongly correlated with vegetation densities above
12" (30 cm - i.e. taller vegetation), especially vegetation between $46 \mathrm{~cm}$ and $91 \mathrm{~cm}$, while FACTOR 2 emphasizes vegetation densities between $7.5 \mathrm{~cm}$ and $23 \mathrm{~cm}$.

While there is a high degree of overlap among the four species of emberizines at this site, there are nevertheless some significant differences among their preferred habitats. The mean foliage profiles of the four species are shown in Figure 1. Savannah sparrows are most distinct, preferring plots where the grass and forb cover is high. This species occupies quadrats with significantly denser vegetation $<9$ " than does Vesper and Brewer's sparrow, and is significantly denser than White-crowned sparrow plots < 6". In these same preferred Savannah sparrow plots, the vegetation is significantly less dense than Brewer's sparrow in the range 18"-42", than Vesper sparrow in the range 18"-36", and than White-crowned sparrow in the range 18"-30". Note that Savannah sparrow and Brewer's sparrow are the same body size (the other two species are larger), and in these two species the habitat preferences are most distinct.

Mean vegetation profiles for the Brewer's, Vesper and White-crowned sparrows show no significant differences, with the single exception that Brewer's sparrow preferred habitat is significantly denser around 42" than is that of the White-crowned sparrow.

\section{THE WILLOWS SITE}

The vegetation at this site seems not to have changed dramatically over 25 years (Cody 1974), with the exception that ground-water levels are higher, and there was more ponding as a result of beaver damming activities. This in turn has reduced the patches of forb and meadow vegetation along streamsides and amongst the willow clumps. A partial relocation of the study site was necessitated because of flooding of the old 1966 study area. Overall, the spatial distribution and breakdown of the willows into height categories appears very similar between 1966 and 1991-92, the foliage profile measured in 1992 is shown in Figure 2, whence it is seen that willows around $2 \mathrm{~m}$ high are the dominant cover at the site.

Table 3 summarizes bird census results from the willows study site. Numbers of breeding bird species 
Table 2. Site characteristics and bird community in grass-sagebrush GS site. For each species, "quads occupied" indicates \# of $15 \mathrm{~m} \mathrm{X} 15 \mathrm{~m}$ quadrats within the species' territories, and "breeding pairs" indicates the total number of pairs with territories completely within or partially overlapping the study site. Total breeding density has units of prs/ha.

Study Year

Site area:

Brewer's sparrow

Quads occupied

Breeding pairs

Tot. breeding density

Chipping sparrow

Quads occupied

Breeding pairs

Tot. breeding density

White-crowned sparrow

Quads occupied

Breeding pairs

Tot. breeding density

Vesper sparrow

Quads occupied

Breeding pairs

Tot. breeding density

Savannah sparrow

Quads occupied

Breeding pairs

Tot. breeding density

\section{SUMMARY}

Total breeding spp.

Total bird density
1966

4.97 ha

108

6

0.92

0

$--$

45

2

0.26

129

4

0.78

67

4

0.44

4

2.40
1991

4.97 ha

$4.66 \mathrm{ha}$

101

5

9

0.82

1.15

1992

0

1

0.04

18

31

2

0.26

2

0.26

55

83

5

4

0.62

0.62

40

74

5

6

0.50

0.75

5

4

2.24

2.78

Species also commonly present

Cliff swallow Petrochelidon pyrrhonota

Brewer's blackbird Euphagus cyanocephalus

$++\quad++\quad+$

Brown-headed cowbird Molothrus ater

$++\quad++$

$++$

Starling Sturnus vulgaris

$+$

$+$

$+$

$+$ 


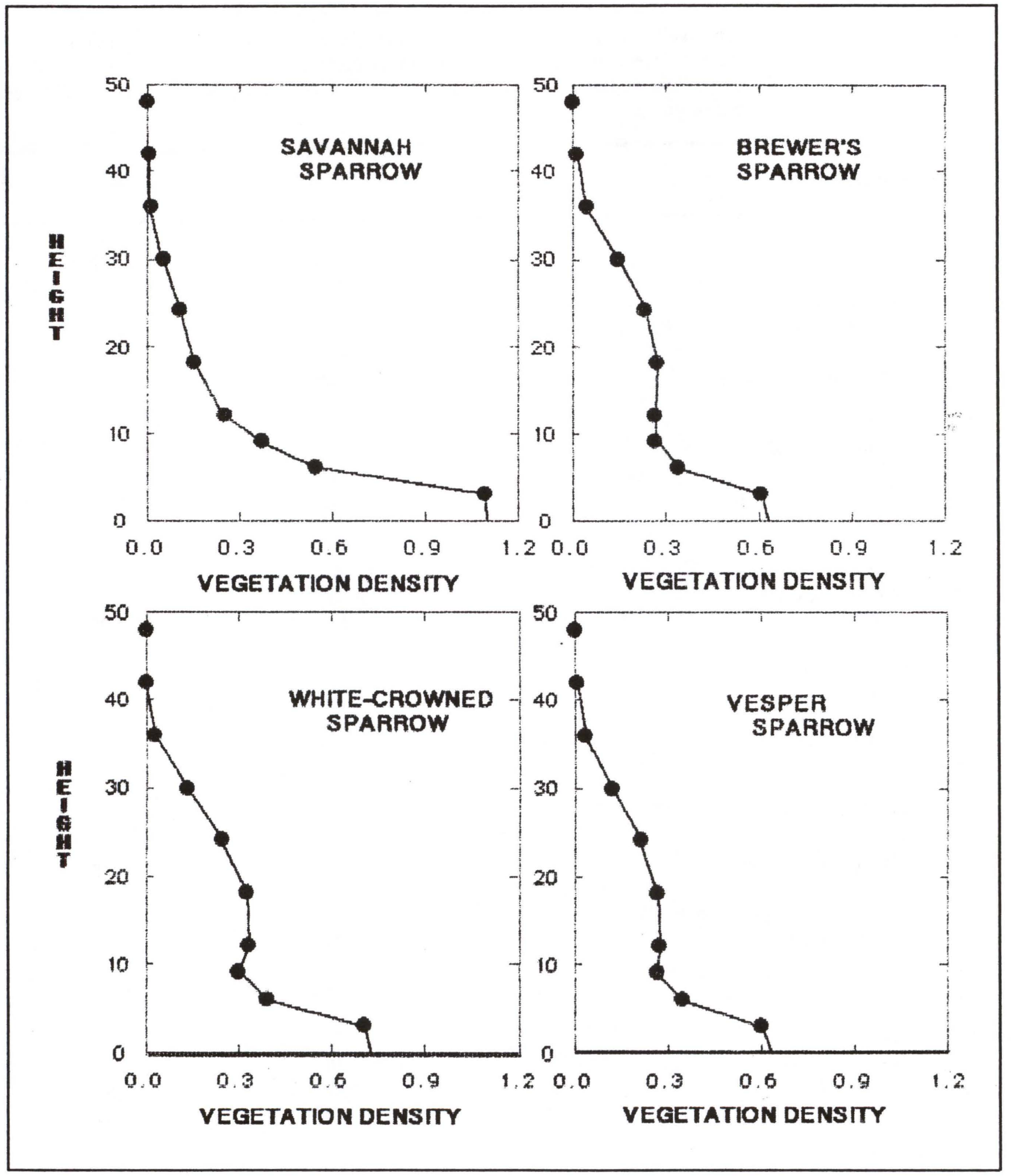

Figure 1. 
Table 3. Site characteristics and bird community in the willows GS site. For each species, "quads occupied" indicates \# of $15 \mathrm{~m} \mathrm{X} 15 \mathrm{~m}$ quadrats within the species'territories, and "breeding pairs" indicates the total number of pairs with territories completely within or partially overlapping the study site. Total breeding density has units of prs/ha.

Year of census:

1966

1991

1992

Site area

2.21

2.20

3.26

Yellow warbler

Quads occupied

\# Breeding pairs

61

8

62

113

Tot. breeding density

1.99

8

11

Wilson's warbler

Quads occupied

48

1.00

2.61

\# Breeding pairs

Tot. breeding density

1.55

0.40

Northern yellowthroat

Quads occupied

\# Breeding pairs

Tot. breeding density

MacGillivray's warbler

Quads occupied

\# Breeding pairs

Tot. breeding density

\section{5 \\ 1}

0.09

Northern waterthrush

Quads occupied

\# Breeding pairs

0

1.45

2.06
0

0

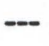

Tot. breeding density

Trail's flycatcher Empidomax traillii

Quads occupied

\# Breeding pairs

Tot. breeding density

0.36

37

2

34

0.50

2

0.37

Lincoln's sparrow

Quads occupied

\# Breeding pairs

80

36

48

6

6

5

Tot. breeding density

1.99

1.27

0.92

Fox sparrow

Quads occupied

58

41

55

5

Tot. breeding density

1.00

1.04 
Table 3 (continued)

Year of census

1966

1991

1992

Song sparrow

Quads occupied

27

27

62

\# Breeding pairs

3

5

8

Tot. breeding density

0.90

1.36

1.44

White-crowned sparrow

Quads occupied

71

31

32

\# Breeding pairs

6

Tot. breeding density

1.36

3

3

0.82

0.64

Clay-colored sparrow

Quads occupied

28

\# Breeding pairs

3

Tot. breeding density

Savannah sparrow

Quads occupied

0

0

9

\# Breeding pairs

$--$

$--$

1

Tot. breeding density

Swainson's thrush

Quads occupied

\# Breeding pairs

Tot. breeding density

0

0.06

Calliope hummingbird

Quads occupied

\# Breeding pairs

Tot. breeding density

0

7

$--$

0.09

Marsh wren

Quads occupied

0

0

10

\# Breeding pairs

$--$

$--$

1

Tot. breeding density

0.25 
Table 3 (continued)

Year of census

Summary totals for above 15 mapped species

$\begin{array}{lccc}\text { \# Species breeding } & 12 & 8 & 13 \\ \text { Tot. breeding density } & 14.93 & 9.77 & 10.09 \\ \text { \# Paruline spp } & 4 & 3 & 4 \\ \text { Tot. breeding density } & 6.97 & 5.00 & 5.25 \\ \text { \# Emberizine spp } & 5 & 4 & 5 \\ \text { Tot. breeding density } & 5.97 & 4.27 & 4.10\end{array}$

Other species commonly present at site

Black-billed magpie Pica pica

\# Breeding pairs

Cliff swallow Petrochelidon pyrrhonota

$$
++\quad++\quad+
$$

were similar (13 vs. 14) in 1966 and 1992, although the 1966 tally included MacGillivray's warbler and Clay-colored sparrow absent in 1992, and the 1992 tally includes Northern waterthrush, Marsh wren, and Savannah sparrow, absent in 1966 . Species numbers were reduced to 9 in 1991 (a late and wet year), when the five species just listed were absent, as also were Swainson's thrush and Calliope hummingbird.

Despite differences in species numbers and community composition, total bird densities were similar in the main guilds, foliage-feeding insectivores (the warblers) and emberizines (sparrows) between 1991 and 1992 (9.27 pr/ha vs. $9.35 \mathrm{pr} / \mathrm{ha} ; 1 \%$ difference). However, bird densities in these two guilds were substantially higher in 1966 (by nearly $40 \% ; 12.94 \mathrm{pr} / \mathrm{ha}$ ). The main density changes can be summarized as follows:

a) Some species showed relatively constant densities across the whole census period 1966-1992 (Willow flycatcher, Fox sparrow). b) Some species were either commoner or present only in 1966 (Northern yellowthroat, MacGillivray's warbler, Lincoln's sparrow, Claycolored sparrow, White-crowned sparrow, Swainson's thrush, Calliope hummingbird).

c) Three species were present only in 1992 (Marsh wren, Northern waterthrush, Savannah sparrow), and a fourth species was present in higher densities that year (Song sparrow).

d) Yellow warblers and Wilson's warblers were present in similar densities in 1966 and 1991, but the former was more common, and the latter rarer in 1992.

e) The combined densities were comparable across years in the three emberizids that favor the wetter sites, Lincoln's, Fox and Song sparrows. However, the two species of emberizines that are typical of drier sites, White-crowned sparrow and Clay-colored sparrow, show declining densities across years. 


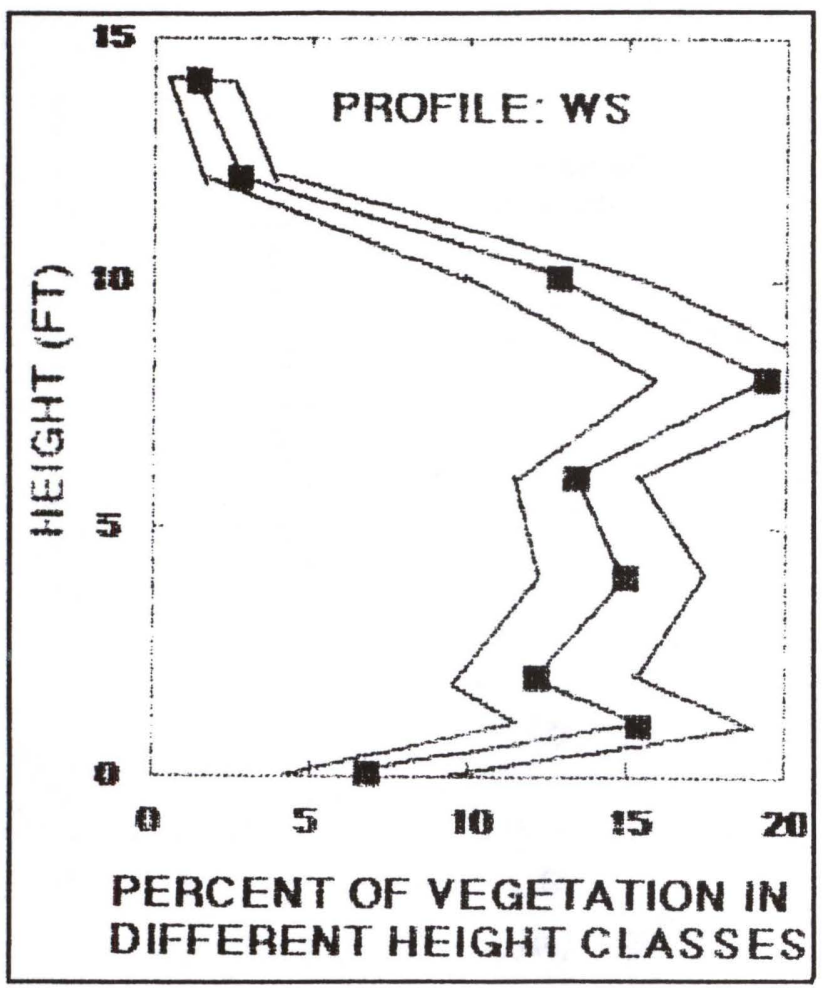

Figure 2. Percent of vegetation in different height classes.

Together with the absence or severe reduction of the ground-foraging thrush and the hummingbird, these results seem to indicate that, with overall wetter conditions and a later 1991 season, the bird community has shifted correspondingly to disfavor those species that customarily forage on drier ground (thrush, two emberizids), or on late-blooming flowers (the hummingbird). However, three of these four species were common in other GTNP habitats in both 1991 and 1992. But the Clay-colored sparrow could not be located anywhere in the park in either of the later census years, whereas it was reasonably common in several locations in 1966 (e.g. up the Gros Ventre riverine meadow and edge habitats). Whether there has been a population status change in this species, which is here on the extreme western edge of its range, remains to be seen following further work. Populations further east and north, towards the center of the species' geographical range, seem not to have declined over the last decade (fide B. MacGillivray, Alberta, and S. Johnson, Stuttsman Co., S. Dakota, pers comm.).
The degree to which the warbler species at the plot select territories with different vegetation is shown in Figure 3. The "standardized profile" relates the vegetation found within the species' territories to that of the site as a whole, as a function of vegetation height; the vertical dashed lines represent \pm 2 S.E. of the mean values for the site, and values greater or less than these indicate significant avoidance (negative values) or preference for (positive values) the vegetation at that height. Note that the commonest species at the site, Yellow warbler, accepts vegetation in just the frequencies in which occurs at the site. In contrast, Wilson's warbler prefers quadrats with more taller (FT6, 8, $10,12)$ and less short (FT2) vegetation, Northern yellowthroat quadrats with significantly more low willows (FT2), and Northern waterthrush habitat is in particular extensively covered with open water (FTO).

Figure 4 provides similar information on the five species of emberizines present. The commonest of these, Song sparrow, is nearly as much a habitat generalist as is Yellow warbler, with almost no deviation from site averages in the vegetation within its territories. On the other hand, Lincoln's sparrow prefers drier sites (viz. low FT0) with more vegetation of medium height (FT4, FT6), and Fox sparrow also drier sites, but those with more taller vegetation (FT6, FT8, FT14). White-crowned sparrows display a distinct preference for dry and grassier quadrats (FT1), which also have more clumps of taller willows. Savannah sparrows are most distinct, using only quadrats with very extensive grass cover, and significantly little in the way of willows vegetation.

The four remaining species whose territories were mapped are shown with relative foliage profiles in Figure 5. Willow flycatchers select areas with extensive and continuous cover of taller vegetation, while Marsh wrens are found only in sites with extensive open water and little cover of lower vegetation. The quadrat samples for Calliope hummingbirds and Swainson's thrushes are small, but appear to indicate a preference for grassier sites in the former, and a strong preference for quadrats with the tallest willows in the latter.

These habitat preferences are in general accord with those reported from the site earlier (Cody 1974). 


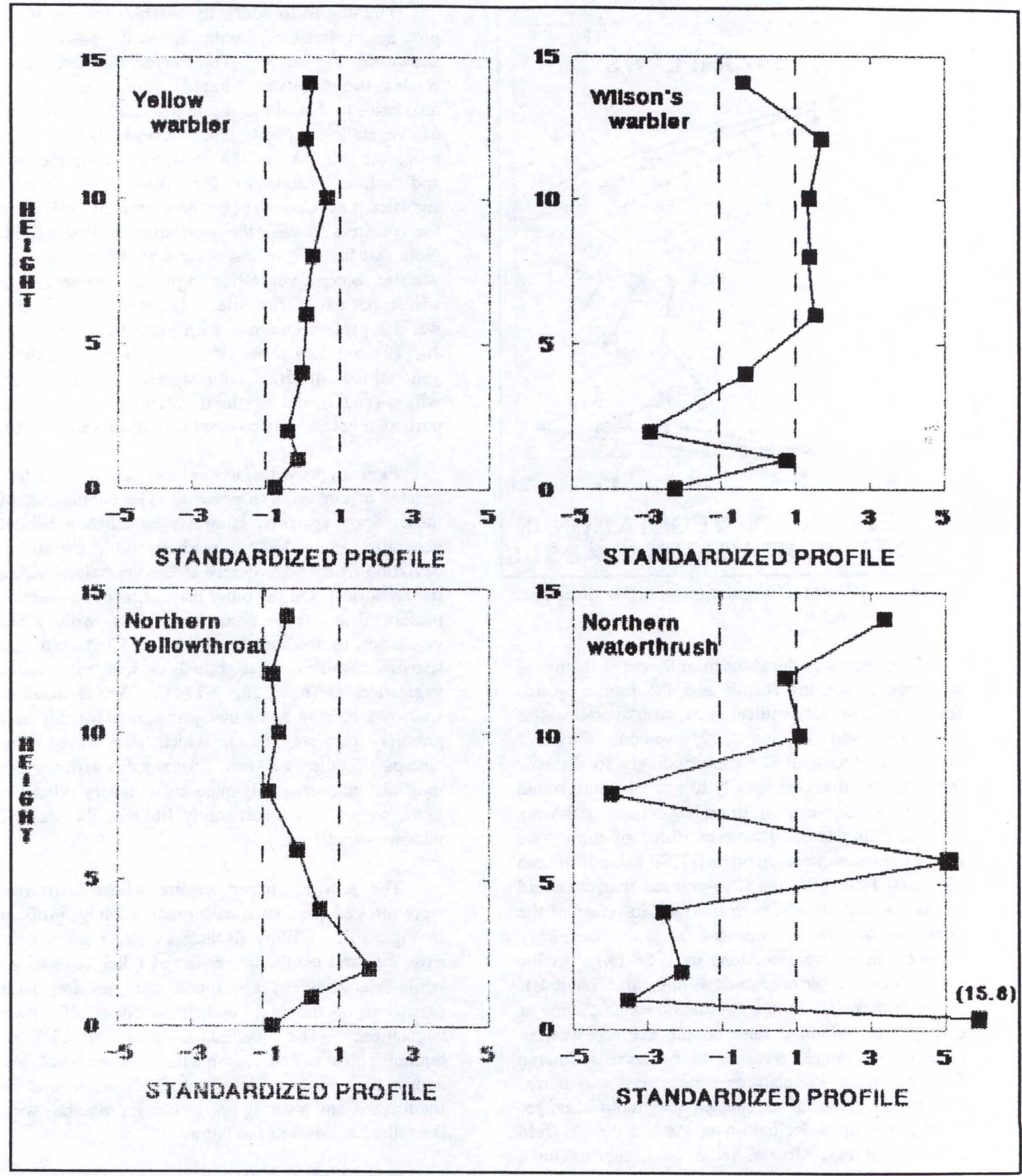

Figure 3. 


\section{VARIATIONS IN BIRD SPECIES AND DENSITIES}

There are in general four sorts of factors that might be examined to interpret variations in bird species densities, within and between sites, and between years. Three of these are intrinsic to the sites: variations in a) vegetation or b) food abundance, which are tracked by the species, or c) variations in other consumer species, which are capitalized on via density compensation. One is extrinsic: d) density variation might be determined by factors in wintering areas or during migration between wintering and breeding areas.

Vegetation differences over the 25-year period appear insignificant in the GS site, which from both photographs and from vegetation measurements appears extremely similar now to when it was first studied. The WS site is certainly wetter now than previously, and this seems the obvious reason for some differences in both species composition and species densities. Species preferring wetter habitat, such as Marsh wren and Northern waterthrush, occurred in 1992 in WS (though not in 1991). The ground-foraging thrush is rare at the site now, whereas before it was common, and it remains common in other habitats within GTNP. And with the flooding of much of the grassier habitat along streamsides, Calliope hummingbird is now rare at the site, although common elsewhere. The flycatcher depends on taller willows whose density and distribution have not been altered by flooding, and it has maintained a rather even density across years.

Of the emberizines, Song sparrow and Lincoln's sparrow are both common, with a preference in the former species for wetter sites, and in the latter for drier sites. Correspondingly, the former has increased in abundance at the WS site over the years, and the latter has declined (Table 3). While Fox sparrow densities have remained nearly constant, White-crowned sparrows have declined, again correlated with reduced areas of drier meadowland within the willows, a habitat for which this species shows a preference.

Habitat selection, i.e. preferences for certain subsets of the vegetation quadrats, has obvious correlations with foraging mode and foraging height distributions. I illustrate this here with the WS warbler species. Figure 6 illustrates this; in all years
Northern yellowthroat forages at the lowest heights in the vegetation, Yellow warbler forages above yellowthroats, and Wilson's warbler generally above the Yellow warblers. In 1966, when MacGillivray's warblers are present, this species forages higher than the other three warblers. These differences in foraging height distributions correspond to the differences in preferred quadrat usage, with yellowthroats commonest in lowest vegetation, Wilson's warblers commonest in the tallest vegetation, and Yellow warbler intermediate.

With these differences in mind, it is illuminating to consider inter-year differences in warbler densities and the corresponding shifts in foraging height distributions. In particular, 1992 had a much reduced density of Wilson's warblers (26\% of 1991 numbers). Correlating with this reduction, Yellow warblers (which are $31 \%$ denser in 1992) shift to foraging higher in the vegetation, and Northern yellowthroats (33\% denser in 1992 relative to 1991) also shift their foraging to higher levels in the vegetation. It appears than some interspecific density compensation occurs at the site, with the reduced density of Wilson's warblers allowing increased density and expanded foraging ranges of the remaining two warbler species.

These warblers are foliage-gleaning insectivores, and it is possible that some of the inter-year variations in densities are attributable to varying levels of resource abundance at the site. A measure of insect availability to the warblers comes from Tanglefoot catches of insects. Insect catch data from four years are shown in Figure 7 (n.b. though not available for 1966). Note that the estimated insect density varies nearly three-fold among years (highest in 1974, lowest in 1991). In 1991 insect densities were lowest, and this year paruline densities were also the lowest measured. In 1992 insect densities were measured nearly $2 / 3$ higher than in 1991 . It is also relevant that insect densities have declined from the 1970's to the present particularly at ground level, where Swainson's thrushes, white-crowned sparrow, and other emberizines forage.

The density of several species appears to be controlled by factors extrinsic to the GTNP habitats. Wilson's warbler was rare not only in the WS site in 1992 , but was unusually scarce throughout the park. MacGillivray's warbler appears to have declined dramatically since the 1960 's. Not only was it absent 

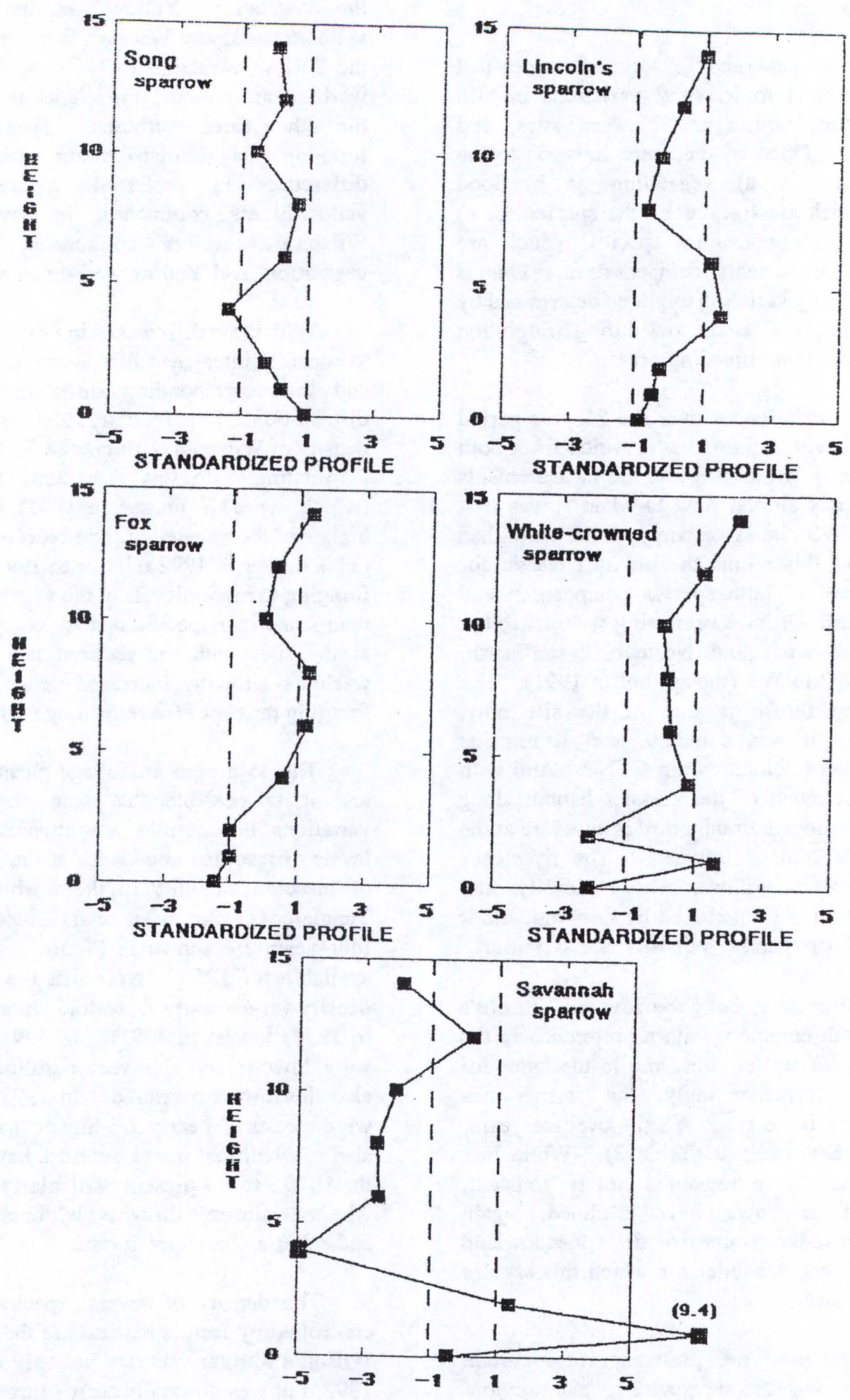

Figure 4. 


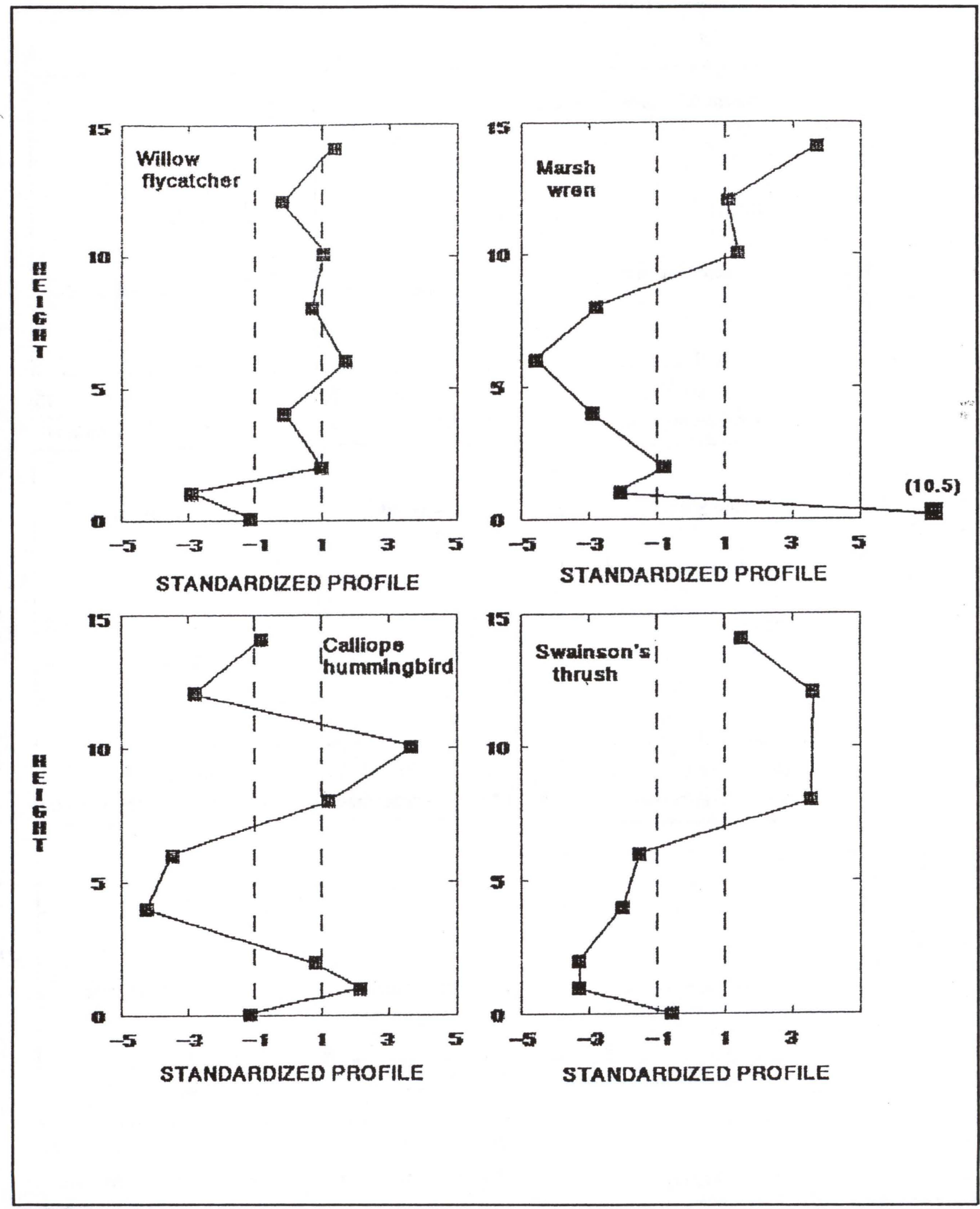

Figure 5. 


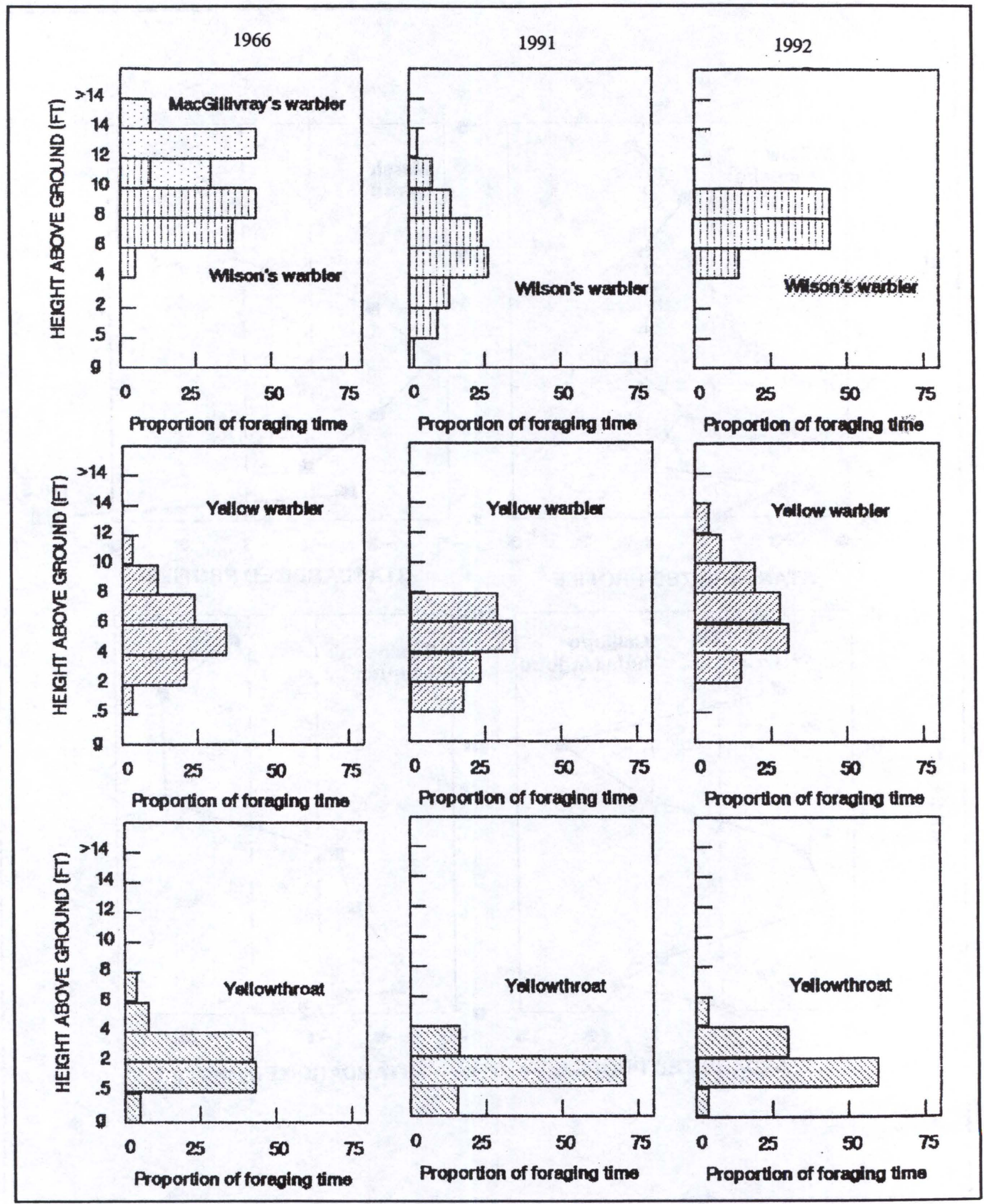

Figure 6. 


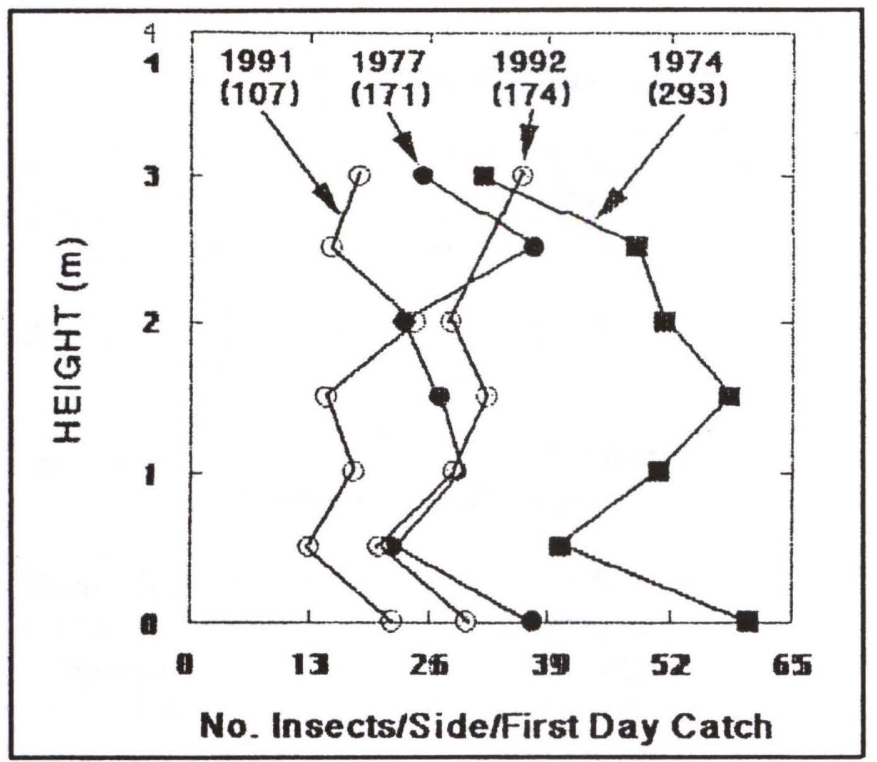

Figure 7.

from WS in the 1990's, but it was extremely sporadic in other GTNP habitats, including those (willowsaspen, low and dense aspen stands) in which it customarily reaches maximal densities. A survey of park habitats in 1992 revealed that MacGillivray's warblers were common only in a few mixed aspen sites at the southern end of the park (Teton Village road), which was quite a contrast to its previous broad distribution and high densities.

Clay-colored sparrow remains the most enigmatic species, for while it was relatively common in the 1960's, a determined search over a variety of suitable park habitat in both 1991 and 1992 failed to produce a single example of this bird. Teton Science School personnel have likewise failed to find it. It appears to have withdrawn eastwards into the more central areas of its range, where it remains at its usual breeding densities (see above).

\section{INTERSPECIFIC INTERACTIONS}

Tests for interspecific interactions over habitat reveal that such interactions modify habitat selection in the GS habitat, but not in the WS site. Such test are conducted as follows, using Savannah sparrow as an example. All quadrats at GS are compared to the mean profile for Savannah sparrow. Some 41/208 fall within one S.D. of Savannah sparrow means, over all heights, and I refer to these quadrats as "1.0
S.D. CORE" for this species. Savannah sparrows actually occupy $32 / 41$ of these quadrats, for an occupancy figure of 0.780 (see Table 4). For "1.5 S.D. CORE", Savannah sparrow occupancy drops to $52 / 86=0.605$. Now, of this latter quadrat set, $30 / 30$ are unoccupied by any other species, 51 are occupied by one or two other species, and 5 are occupied by all three other emberizines. Savannah sparrow occupancy of its CORE habitat declines with increasing co-occupancy, from 0.900 to 0.471 to 0.200 (see Table 4).

The closest species to Savannah sparrow in habitat preference is Vesper sparrow, and we might expect to see some interactions especially between these two species. Of the $\mathbf{8 6}$ quadrats which are Savannah sparrow CORE, 62 are also Vesper sparrow core by the same criteria. In these 62 quadrats, Savannah sparrow's occupancy declines to 0.516 (it tends to avoid habitat preferred by Vesper sparrow). Further, of the 86 Savannah sparrow CORE quadrats, 29 are actually occupied by Vesper sparrow, and these are co-occupied by Savannah sparrow to the extent of 0.483 . Finally, some 24 quadrats are both Savannah sparrow and Vesper sparrow CORE, and are also occupied by Vesper sparrow; of these, Savannah sparrow co-occupies a proportion 0.416 (see Table 4). These declining occupancy figures for Savannah sparrow as its CORE habitat a) coincides with Vesper sparrow CORE, and b) is occupied by Vesper sparrows, indicate the extent to which Savannah sparrow's choice and occupancy of habitat is limited by the presence of Vesper sparrows.

Detailed analysis of quadrats utilized, quadrats suitable but not utilized, and the utilization of suitable quadrats by other than the subject species might reveal subtle interspecific interactions among the species of the WS also. Certainly some density compensation appears to operate there, but whether the presence of one species inhibits habitat use by another remains to be seen from further analysis.

\section{- DISCUSSION}

A comparison of bird species composition and densities in two GTNP habitats over a 25 -year period reveals both strong similarities and some considerable differences. Some of the differences are attributable to changes in habitat, specifically to water levels 
Table 4. Interactions among species in the GS site.

Occupancy of "1.0 S.D. CORE" habitat by savannah sparrow: 0.780 Occupancy of "1.5 S.D. CORE" habitat by savannah sparrow: 0.605

Occupancy of "1.5 S.D. CORE" habitat by savannah sparrow when unoccupied by any other spp.: $\quad 0.900$ occupied by one or two other spp.: occupied by three other spp.: $\quad 0.200$

Occupancy of "1.5 S.D. CORE" habitat by savannah sparrow when habitat is also vesper sparrow core: $\quad 0.516$ when habitat is also occupied by vesper sp.: $\quad 0.483$ when habitat is both vesper sp. core and 0.483 also occupied by vesper sparrow: 0.416

within the WS site. Others are attributable to presumably normal inter-year variations in climate, e.g. the cool, wet and late Spring in 1991. Yet other differences appear beyond the control of factors that operate within the park, and specifically the reduced densities of two warbler species (Wilson's, MacGillivray's) are not readily explained by any changes in resource availability during the Jackson Hole breeding season. The broad patterns of habitat preferences, foraging height distributions, and interspecific interactions are similar now to what was observed 25 years ago, but shifts in relative densities require both a detailed interpretation of within-site factors and invocation of extrinsic factors for their resolution.

\section{- CONCLUSIONS}

Breeding densities of songbird species in Jackson Hole vary apparently in both the short term and the long term. At least some of the former variation is explicable via within-site variation in resource density and availability, and some of the longer term variation might well be attributable to longer-term environmental changes in situ such as those related to beaver density and activity. But a component of the long term variation remains unexplained, and might well be related to factors that affect the success of birds in completing their migrations and to their success or otherwise in overwintering at lower latitudes. The establishment of a permanent monitoring program, within GTNP, for migrant bird breeding densities is the only way to assemble and evaluate the data necessary to answer such questions, and this must be recognized as an important priority for forthcoming research.

\section{- Literature Cited}

Cody, M. L. 1974. Competition and the Structure of Bird Communities. Monogr. Pop. Biol., Princeton Univ. Press, Princeton, N. J.

Cody, M. L. 1985. Habitat Selection in Birds. Academic Press, Orlando, FL.

Diamond, J. M. \& T. J. Case. 1986. Community Ecology. Harper \& Row, N. Y.

Hutto, R. L. 1980. Winter habitat distribution of migrant landbirds in western Mexico, with specific reference to foliage-gleaning insectivores. In: A. Keast and M.Morton (eds; q.v.).

Hutto, R. L. 1986. Migratory landbirds in western Mexico: a vanishing habitat. Western Wildlands 11:12--16.

Keast, A., and M. Morton (eds.). 1980. Migrant Landbirds in the Neotropics: Ecology, Behavior, Distribution and Conservation. Smithsonian Inst., Washington, D.C.

Smithsonian Institute. 1991. Birds Over Troubled Forests. Smithsonian Migratory Bird Center, Laurel, MD.

Terborgh, J. 1989. Where Have All the Birds Gone? Princeton Univ. Press. Princeton, N. J.

Wiens, J. 1984. Habitat selection in variable environments: shrub-steppe birds. Ch. 7 in Cody 1985, q.v.

Wiens, J. 1988. Community Ecology of Birds. Cambridge Univ. Press, v. 1,2. 